\title{
Numerical Assessment of Bioclimatic Architecture Strategies for Buildings Design in Tropical Climates: A Case of Study in Panama
}

\author{
Miguel Chen Austin ${ }^{1}$, Milvia Castillo ${ }^{1}$, Ángela de Mendes Da Silva ${ }^{2}$, and Dafni Mora ${ }^{1,3, *}$ \\ ${ }^{1}$ Faculty of Mechanical Engineering, Universidad Tecnológica de Panamá, Panama City, Panama \\ ${ }^{2}$ Faculty of Engineering and Architecture, Universidad Interamericana de Panamá, Panama City, \\ Panama \\ ${ }^{3}$ Centro de Estudios Multidisciplinarios de Ingeniería, Ciencia y Tecnología (CEMCIT-AIP), \\ Panama City, Panama
}

\begin{abstract}
The increasing concern expressed by building designers in Panama, due to new building-energy regulations, regarding sustainable development goals and energy efficiency, is leading architects to reanalyse their design strategies and evaluate the vernacular architecture. The main implications of the hot-humid climate characteristics stipulate that the need for cooling of indoor environments drives buildings' design and settlements. This work aims to assess the use of bioclimatic architecture strategies in three existing building typologies design in Panama, in terms of thermal comfort performance. The approach adopted here is to compare and analyse the vernacular architecture with current architecture. Besides, to evaluate bioclimatic architecture strategies based on recent investigations and the guidelines proposed by Givony, Olgyay, among others. A numerical assessment was performed on the dynamic simulation software DesignBuilder, where the building's passive strategies are evaluated in terms of operative temperature, relative humidity ( $\mathrm{rH}), \mathrm{PMV}$, PPD, and discomfort hours (DH). All three houses, the HVA, HCA, and HRES were tested in three different locations within Panama City. Results showed that the strategies in HVA perform best for reducing $\mathrm{rH}$ levels, but the HRES performs best in overall thermal comfort performance, apart yet from the high $\mathrm{rH}$ levels encountered.
\end{abstract}

\section{Introduction}

The current situation has increased calls to action, such as those recently established at the climate conference in Paris (COP21), which seeks to restrict the increase in greenhouse

\footnotetext{
* Corresponding author: dafni.mora@utp.ac.pa
} 
gas emissions by maintaining the global average increase below $2^{\circ} \mathrm{C}$. Consequently, new building-energy regulations in Panama (Sustainable Buildings Regulation (RES in Spanish): approved in June $\left.26^{\text {th }}, 2019\right)$, regarding the sustainable development goals (ODS) and energy efficiency, have increased the concern expressed by building designers and is leading architects to reanalyse their design strategies [1,2]. The main implications of the hot-humid climate characteristics stipulate that the need for cooling of indoor environments drives the design of buildings as well as settlements. The reduction of energy consumption associated with the use and construction of buildings and the increase in energy efficiency in their climatic conditioning are issues that are receiving significant attention, both from the scientific-technical and business point of view [3].

The sustainable development (SDG) guide refers to the design of new buildings efficient in energy consumption. This SDG began in 2013, however, in 2011 Panama already had around 15 projects that were developed under the green building standard; with an initiative that examined opportunities to promote sustainable construction (green buildings) in Panama and establish a proportion of energy consumption that is intended to decrease by implementing active and passive measures in building design [2].

Panama considers in its energy policies and its 2015-2050 National Energy Plan, laws of rational and efficient use of energy, as well as educational programs, in which efforts are made to build with more energy-efficient designs (less polluting and thermally suitable materials) or to modify existing buildings for efficiency. This before, to provide the population with recommendations for the appropriate use of household appliances, equipment, air conditioning, and to raise awareness of the impact of their misuse, maintenance, and equipment life and on the individual economic situation.

Thus, the present work aims to assess the use of bioclimatic architecture strategies for buildings design in Panama, focusing primarily on achieving thermal comfort through dynamic simulations. The approach adopted here is to understand and analyse the vernacular architecture mentioned above, and bioclimatic architecture strategies based on recent investigations and the guidelines proposed by the architects Olgyay and Givoni. This analysis is expected to provide possible passive cooling strategies that can be implemented for achieving occupants' thermal comfort.

Moreover, a model of the resulted bioclimatic building design is developed on the dynamic simulation software DesignBuilder, where the building's passive strategies are evaluated in terms of achieving or not the occupants' thermal comfort. Furthermore, the resulted bioclimatic building design will be compared to a conventional building design under the same climatic conditions but based on the new building-energy regulations approved in Panama. The comparison analysis also contemplates an evaluation of the energy consumption between these three building designs.

\subsection{Aspects of the bioclimatic architecture and strategies in tropical climates}

In the conception of bioclimatic architecture, the climate is the most critical element where in most cases, it does not offer the conditions that allow living comfortably throughout the year, so it is necessary to correct it with the capacity of the building seeking first the wellbeing of the occupants and second promoting energy savings and protection of the environment. However, humanity is becoming increasingly aware of the high price of energy and environmental damage, and thus, countries are adopting bioclimatic measures in entire buildings and urbanizations $[4,5]$. Besides, the microclimate plays an essential role in energy consumption and feelings of comfort in outdoor spaces.

On the other hand, different studies support the energy-saving capacity of up to $70 \%$ in architectural solutions, from a logical adaptation to the climate. For this, the heat 
interactions between the indoor and outdoor environment need to be correctly used by taking advantage of the resources offered by nature (light, wind, vegetation, soil humidity, environmental temperature, among others), maximizing the energy efficiency of buildings and minimizing the use of mechanical air conditioning systems [6,7].

Bioclimatic architecture prefers passive systems in its architectural designs, where such systems' performance depends on the quality and precision of the architectural concept. Such passive systems allow us to modify the temperature or humidity of a space through the orientation, geometric shape, sun protection, ventilated ceilings, windows and vents, the colour of roof and external walls, among others, in pursuit of reducing energy consumption and minimizing negative impacts on the environment. All this tends to improve the quality of the indoor environment and the life quality, but depending on the climate, it may not be enough to adequately condition a building in all seasons of the year [8,9].

Moreover, various studies undertaken in countries presenting tropical climates such as in Panama, evaluated different bioclimatic architecture strategies to undercome different climate-related problem [6], [10-13], such as high humidity, solar insulation, where some of them implemented technological tools [14] (Table 1).

Finally, recent studies in Panama $[15,16]$ suggest that the deliberated implementation of insulation negatively affects the natural response of the thermal mass, and therefore its use in tropical climates must be carefully analysed. It is also essential to highlight the influence of the windows distribution and WWR, which can considerably improve the thermal performance. This roof insulation application agrees with the highlights reported in [17], where its coupling with roof ventilation strongly influences the indoor thermal comfort.

Table 1. Recommendations for the application of bioclimatic architecture strategies in tropical climates.

\begin{tabular}{|c|c|c|c|c|}
\hline & \multicolumn{4}{|c|}{ Recommendations } \\
\hline Strategies & Peru [6] & $\begin{array}{c}\text { Dominic } \\
\text { Republic [14] }\end{array}$ & Nicaragua $[10]$ & Mexico $[12,13]$ \\
\hline Climate & Humid tropical & Subtropical & Humid warm & Warm subhumid \\
\hline $\begin{array}{l}\text { Materials } \\
\text { and } \\
\text { thermal } \\
\text { mass }\end{array}$ & $\begin{array}{l}\text { Low thermal mass } \\
\text { and insulation for } \\
\text { roofs with a slope } \\
\text { less than } 80 \% \text {, to } \\
\text { prevent thermal } \\
\text { radiation storage. }\end{array}$ & $\begin{array}{l}\text { Ceramic floor and } \\
\text { pitched } \\
\text { roof finished in } \\
\text { terracotta tiles. }\end{array}$ & $\begin{array}{l}\text { Thermal inertia is not } \\
\text { always an advantage, } \\
\text { due to weak day-night } \\
\text { temperature } \\
\text { variations, and } \\
\text { lightweight insulation. }\end{array}$ & $\begin{array}{l}\text { Walls with low } \\
\text { thermal } \\
\text { conductivity. } \\
\text { Semi-permeable } \\
\text { cover. }\end{array}$ \\
\hline Orientation & $\begin{array}{l}\text { Spaces facing } \\
\text { north protected } \\
\text { from solar } \\
\text { radiation, and } \\
\text { protected } \\
\text { openings, taking } \\
\text { advantage of local } \\
\text { winds. } \\
\end{array}$ & $\begin{array}{l}\text { Southeast, for } \\
\text { living spaces } \\
\text { during the day. } \\
\text { Northwest, } \\
\text { for nocturnal rest } \\
\text { areas, with higher } \\
\text { incidence winds. }\end{array}$ & $\begin{array}{l}\text { North-South with } \\
\text { arrangement of the } \\
\text { longest axes to East } \\
\text {-West. }\end{array}$ & $\begin{array}{l}\text { Elongated in the } \\
\text { North-South } \\
\text { direction }\end{array}$ \\
\hline $\begin{array}{l}\text { Lighting } \\
\text { and } \\
\text { parasols }\end{array}$ & $\begin{array}{l}\text { Windows facing } \\
\text { North and South, } \\
\text { depending on the } \\
\text { prevailing winds, } \\
\text { with horizontal } \\
\text { parasols. }\end{array}$ & $\begin{array}{l}\text { Opaque crystals } \\
\text { with low } \\
\text { emissivity for } \\
\text { windows, } \\
\text { and eaves, } \\
\text { shutters, etc. }\end{array}$ & $\begin{array}{l}\text { Total, and permanent } \\
\text { shading. }\end{array}$ & $\begin{array}{l}\text { Inner courtyard } \\
\text { for lighting. Total } \\
\text { and permanent } \\
\text { shading, with } \\
\text { eaves and } \\
\text { canopies. }\end{array}$ \\
\hline Ventilation & $\begin{array}{l}\text { Maximum use of } \\
\text { the wind; allowing } \\
\text { cross ventilation. }\end{array}$ & $\begin{array}{l}\text { Architectural } \\
\text { elements to direct } \\
\text { air currents into }\end{array}$ & $\begin{array}{l}\text { Promote day and } \\
\text { night cross ventilation } \\
\text { along }\end{array}$ & $\begin{array}{l}\text { Cross ventilation } \\
\text { and chimney } \\
\text { effect. }\end{array}$ \\
\hline
\end{tabular}




\begin{tabular}{|c|c|c|c|c|}
\hline & $\begin{array}{l}\text { Promote the use of } \\
\text { Venturi effect. }\end{array}$ & $\begin{array}{l}\text { the interior } \\
\text { instead of } \\
\text { hindering it. }\end{array}$ & the East-West axis. & \\
\hline Vegetation & $\begin{array}{l}\text { Leafy trees as } \\
\text { palm trees, vines, } \\
\text { and create green } \\
\text { spaces to prevent } \\
\text { indirect radiation. }\end{array}$ & $\begin{array}{l}\text { Cover the surfaces } \\
\text { to reduce the solar } \\
\text { incidence and } \\
\text { generate shade } \\
\text { with intermediate } \\
\text { areas. }\end{array}$ & $\begin{array}{l}\text { Tall tree branches to } \\
\text { provide shade. Trees } \\
\text { and shrubs, especially } \\
\text { in the West building } \\
\text { shade. }\end{array}$ & - \\
\hline $\begin{array}{l}\text { Colours } \\
\text { and } \\
\text { reflections }\end{array}$ & $\begin{array}{l}\text { Use of matte shade } \\
\text { on floors: medium } \\
(40 \%) \text {; Clear walls } \\
(60 \%) \text {; white } \\
\text { ceilings }(70 \%) .\end{array}$ & - & $\begin{array}{l}\text { Reflective colours in } \\
\text { pastel tone range for } \\
\text { they help prevent } \\
\text { glare. }\end{array}$ & - \\
\hline Terrain & $\begin{array}{l}\text { Location as high as } \\
\text { possible to } \\
\text { increase exposure } \\
\text { to winds, and } \\
\text { counteract high } \\
\text { temperatures for } \\
\text { releasing excess } \\
\text { moisture. }\end{array}$ & - & $\begin{array}{l}\text { High elevated sites to } \\
\text { maximize ventilation } \\
\text { and minimize } \\
\text { moisture. Stilt-based } \\
\text { constructions to } \\
\text { obtain greater } \\
\text { exposure to breezes. }\end{array}$ & - \\
\hline $\begin{array}{l}\text { Internal } \\
\text { distribution }\end{array}$ & $\begin{array}{l}\text { High and large } \\
\text { volume spaces } \\
\text { with minimum } \\
\text { interior at a height } \\
3.50 \mathrm{~m} \text {. }\end{array}$ & $\begin{array}{l}\text { It has two levels: } \\
\text { the bedrooms } \\
\text { upstairs, the rest } \\
\text { downstairs. }\end{array}$ & - & $\begin{array}{l}\text { Compact } \\
\text { configuration } \\
\text { with protection } \\
\text { from winds. }\end{array}$ \\
\hline
\end{tabular}

\subsection{Transition of architecture strategies in Panama}

This section is dedicated to briefly present more details about the transition of residential building architecture throughout Panama's buildings development. The primary cultures in Panama were the Cunas, Guaymíes, and Chocoes. In the Guaymíes' house, with a circular building shape at ground level, the external walls were made from planks or white cane, the floors consisted of split palm trunks and the roofs. The Cunas' houses were similar to the Guaymíes' with a rectangular building shape.

The Chocoes' houses were also similar to the Guaymíes', but elevated about 2 or $3 \mathrm{~m}$ [18]. The Colonial architecture was the reason why wood began to be used in homes, but buildings such as churches, town halls, among others, were built out of stone or brick. The three centuries among Spanish people produced an architecture comparable in many ways to the one in the Caribbean basin: multi-story houses with continuous balconies, internal patios, masonry, wood or quincha walls, and tile roofs [19].

The Pre-Columbian architecture was purely artisanal; the use of wood was maintained, with specific significant changes, such as the introduction of new elements and construction technologies: Grooved wood for ceilings, calicanto for external walls, wood for partitions with lattice-shaped ventilation strips, reinforced concrete for balconies, among others [20], [21]. The main influences came from the United States, where there was already a tradition of vernacular architecture applicable to warm-humid contexts.

In 1907, twenty-four houses had been developed for the canal area personnel, which were clearly based on the previous French experience: made of wood, separated from the floor by pillars on concrete bases, and had mesh-covered verandahs and corrugated metal roofs. By 1920, houses moved away from traditional construction methods, and in the 1940s tenant, houses were replaced by reinforced concrete buildings and modern aesthetics 
[20]. Some notable features of the architecture of the 90s were [20]: (i) The replacement of calicanto and wood by reinforced concrete blocks; (ii) Doors and windows, where the use of glass panels became common so that the masonry shutters disappeared little by little; (iii) exterior walls with block and reinforced concrete; (iv) floors out of wood.

Currently, in Panama, the popular homes are mostly built of block and reinforced concrete, the roofs are mostly zinc and others of tiles. In turn, in some regions outside Panama City, wooden houses, quincha houses, and ranches are still preserved, which in turn contrast with the popular houses.

\section{Methodology}

To evaluate the different building architecture typologies in terms of comfort and energy consumption, a 3D model of each typology is developed in the software DesignBuilder to conduct dynamic simulations. Three typologies are wanted to be evaluated (Figure 1): (a) a house considering bioclimatic strategies on tropical areas named here as "vernacular architecture" or HVA, $(b)$ a house with standard construction regulations (before the RES regulation) named here as "current architecture" or HCA, and (c) a house with similar morphology as the latter but considering the new RES regulations named here as "RES based architecture" or HRES. A general schematic of the methodology followed for the numerical evaluation is presented hereafter.

Each house typology is to be tested in three different environments located within Panama City (Figure 1). This before has the purpose of determining the performance of these three typologies under different environments; nine possible combinations (cases) are expected. The performance of each case is compared and evaluated through thermal comfort and energy consumption. The following indicators are employed to evaluate the thermal comfort: the operative temperature level (OT), humidity level $(\mathrm{rH})$, the predicted percentage of dissatisfied (PPD), the predicted mean vote (PMV), and discomfort hours (DH). For energy consumption, only the electricity consumed by the air conditioner is employed. The thermal comfort levels are set to be $26^{\circ} \mathrm{C}$ for the air and radiative temperatures, $50 \%$ for the relative humidity, 1 clo for clothing, and $0.317 \mathrm{~m} \mathrm{~s}^{-1}$ for airspeed, and thus, resulting in the following maximum comfort limit values, determined with the integrated comfort calculator in DesignBuilder: $26^{\circ} \mathrm{C}$ for OT, $15.22 \%$ for PPD, and 0.70 for PMV. It is important to mention that the regulations of Panama, such as the RAV (Regulation of Air Conditioning and Ventilation) and the RES, recognize the ASHRAE 55 standard, thus, to comply with this standard regarding PMV values on the scale 7 points, should be between -0.5 and 0.5 .

The methodology employed for the numerical assessment is straightforward (Figure 2), the first part contemplates a dynamic simulation under the three different environments for each case with no mechanical air conditioning allowed. These three different environments were chosen as to test the performance of three house typologies as shown in Figure 1, in a rather vegetated area with few buildings around (location 1), in an entirely urban area rounded with many buildings (location 3 ), and in a combination of both area types before (location 2).

In order to compare the performance of each typology, in terms of thermal comfort and energy consumption, the most important differences within these three models lay within the morphology of each house rather than the house usage and occupancy. For the HVA model, an existing house of such type was taken as reference $\left(144.06 \mathrm{~m}^{2}\right)$, where its envelope is mostly constituted out of heavyweight wood (taken from DesignBuilder, DB) as part of the floor, external walls, and internal partitions (of $0.20 \mathrm{~m}$ thickness), whit classic type of single windows (with a $50 \%$ of WWR). 


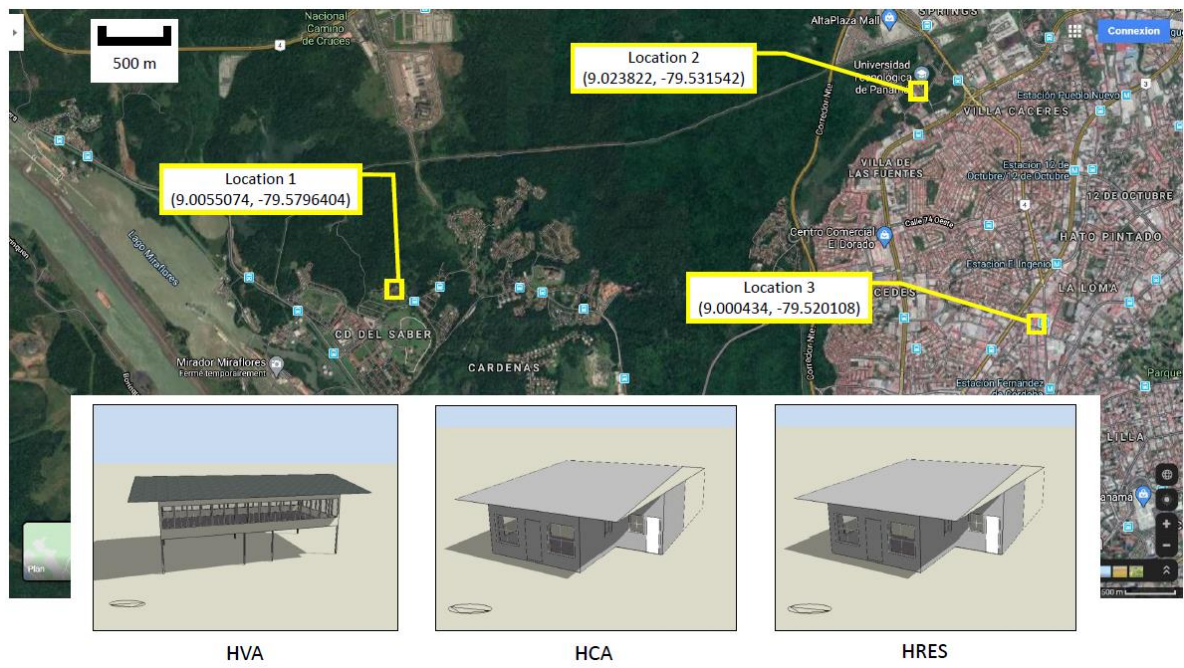

Fig. 1. The house typologies to be evaluated along with the three locations to be tested in.
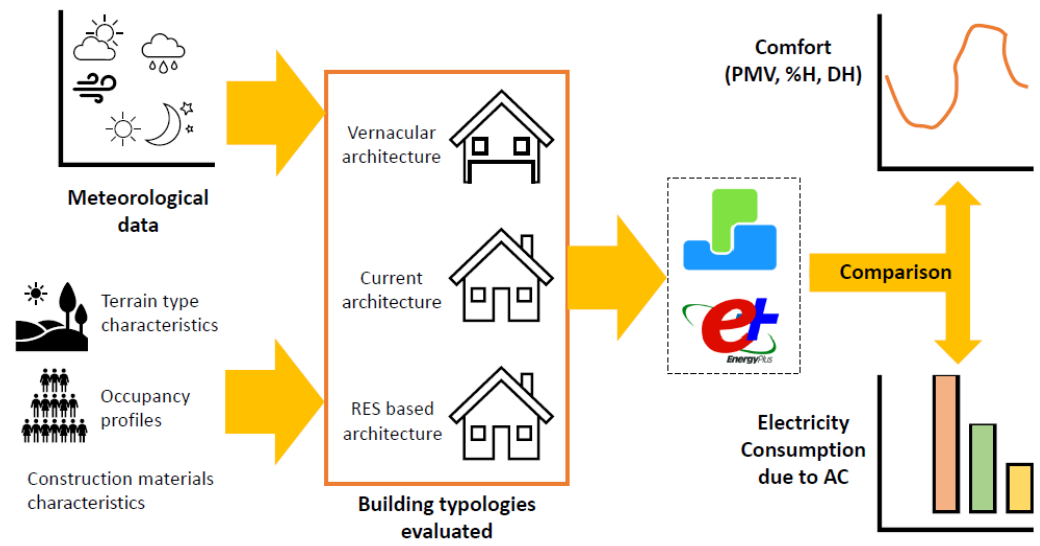

Fig. 2. A general representation of the methodology followed in the numerical study.

The roof is composed of standard concrete tiles as also taken from DB, and the floor is elevated $3 \mathrm{~m}$ away from the ground (Figure 1). For the HCA model, an existing construction was used as reference $(470.37 \mathrm{~m})$, where the envelope is mostly made out of concrete blocks (walls and partitions of $0.12 \mathrm{~m}$ thickness) apart from classic single windows (with a $30 \%$ of WWR). Here, the roof is composed of a $0.005 \mathrm{~mm}$ zinc layer. Finally, the HRES model is similar to the HCA in morphology, but the composition of the roof and the window type were adapted based on the Panamanian RES regulation. These values must be reached when designing a one-story residential building with no air conditioning. A summary of the U-values $\left(\mathrm{W} \mathrm{m}^{-2} \mathrm{~K}^{-1}\right)$ for each variation of the envelope composition, for each typology, goes as follows for the HVA: External walls (0.665), windows (6.121), floor (0.648), roof (0.670). For the HCA: External walls (3.859), windows (6.121), floor (3.487), roof (7.143). For the HRES: External walls (3.859), windows $(5.800 *)$, floor $(3.487)$, roof $(0.500 *)$. Where $(*)$ correspond to values from the RES regulation for windows. 
Regarding the household and occupancy, a standard four-member family type was chosen for each typology, with the same occupancy schedule where the houses were occupied all weekends and between 5:00 to 10:00 p.m. the weekdays. Natural ventilation was allowed for the no air conditioning scenarios all day long with a constant infiltration rate of $0.7 \mathrm{ach}^{-1}$. The simulations are performed monthly for the whole year using meteorological data from 2019, and thus, the resulting values for each thermal comfort indicator are presented as month-averaged values.

The AC equipment in the homes had a COP (coefficient of performance) of 4.40, so it meets the specifications of the RES in Panama and even the RAV. These values must be greater than 3.0 COP for the RES and not less than 2.93 COP, respectively [1]. Regarding Panama regulations, the Air Conditioning and Ventilation (RAV) Regulations and the RES recognize the ASHRAE 55 standard. This mentions that, for interior design in conditioned spaces, the indoor temperature must be maintained below $30^{\circ} \mathrm{C}$ and relative humidity between 50 and $60 \%$ [1].

The second part consists of a preliminary bioclimatic analysis using the bioclimarq ${ }^{2016}$ tool. This analysis is based on Givoni's and Olgyay's charts, along with Mahoney's and Serra \& Coch's tables.

\section{Results analysis and discussion}

\subsection{Evaluation of thermal comfort performance}

Based on the simulation results, it can be observed that the critical months are encountered among January to May (warm, dry season). Regarding the results obtained from the operative temperature (OT) in figure 3(a), it can be observed that the HRES presented temperatures always below $27^{\circ} \mathrm{C}$ throughout the year and locations. However, it was at location 1 where the HRES showed the lowest temperatures, around $26^{\circ} \mathrm{C}$ for much of the year. For the HCA, OT presented intermediate values between the HRES and HVA, with values closer to those of the HRES, only in February. However, in March and April, the OT exceeded the $28^{\circ} \mathrm{C}$ and the rest of the months, they both presented OT lower than $27^{\circ} \mathrm{C}$. On the contrary, the HVA showed high temperatures throughout the year and locations. The OT exceeded $28^{\circ} \mathrm{C}$ for all locations, wherein location 2 exceeds $30^{\circ} \mathrm{C}$ in March and April. This last result may be a consequence of the internal solar heat gains through windows, due to the HVA elevation above the ground and the WWR ratio.

For the behaviour of the relative humidity $(\mathrm{rH})$ presented in Figure 3(d), the HRES presented the highest $\mathrm{rH}$ values, and the HVA presented the lowest $\mathrm{rH}$ values throughout the year and locations, which confirmed the recommendations presented in Table 1 for the terrain. However, for all locations and typologies, the lowest resulting $\mathrm{rH}$ values reached about $60 \%$, indicating that $\mathrm{rH}$ comfort limit is not achieved regarding the limit established before, but it is in accordance with the limits established by the ASHRAE 55 and RAV standards.

The HCA and HRES presented PMV values below 0.5 from April to September, in the different locations (Figure 3(c)). However, the HVA for all locations presented values above -1.5 throughout the year. The HCA and HRES also presented, in their three locations, a PPD below 20\% in the same months (Figure 3(b)), which comply with the ASHRAE 55 and ISO 7730. The HCA and HRES in the different locations, from January to March and September to December, showed PMV values below to 1, where the HRES presented lower values for the three locations. Similarly, the HRES presented the lowest PPD values in those months, specifically location 1 (HRES 1), followed by the HCA. 
However, the HVA presented the highest PPD values, exceeding the 70\% PPD from January to April and from October to December. This before indicates that the HCA and HRES should host the least thermally dissatisfied occupants.
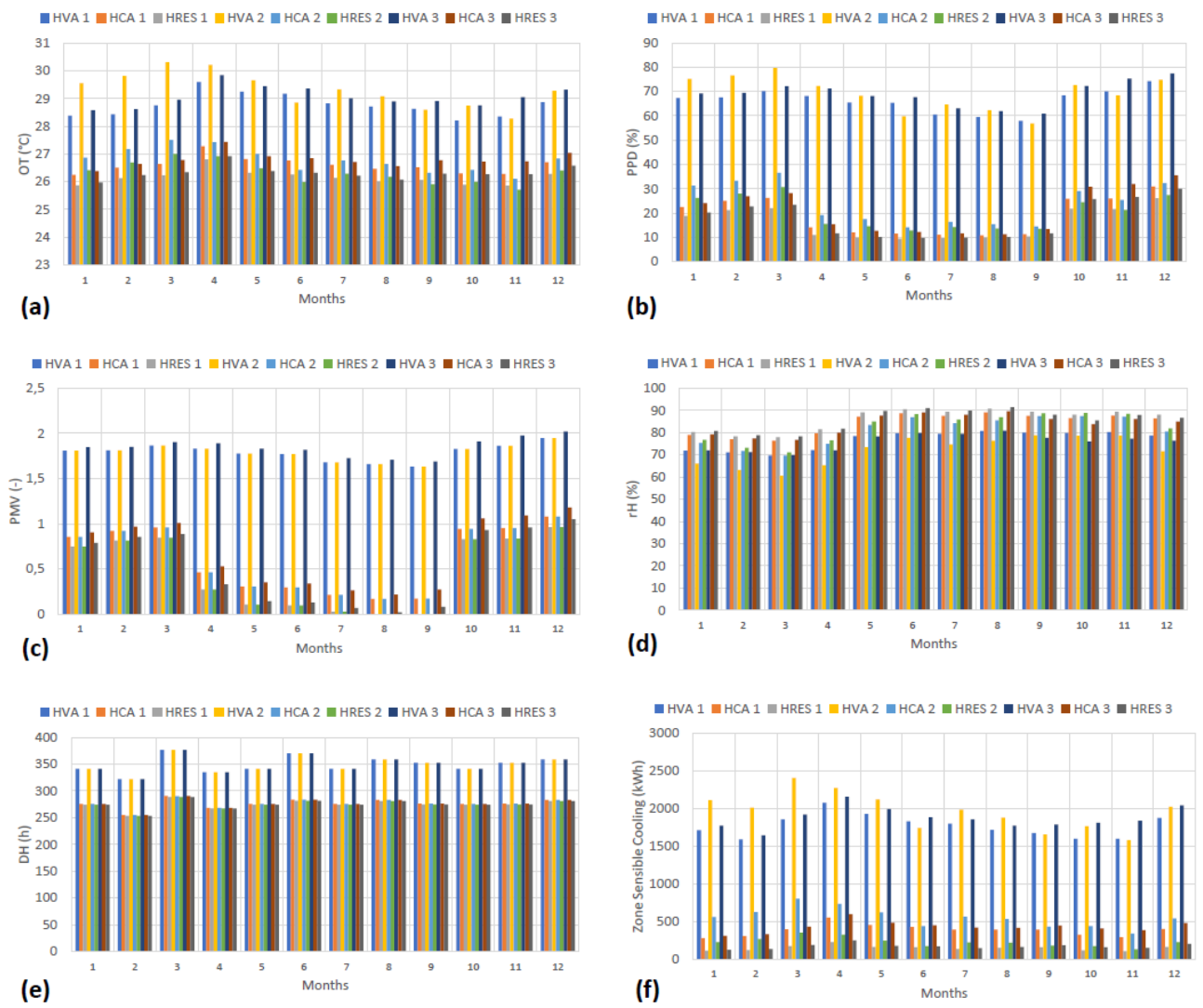

Fig. 3. thermal comfort indicators: (a) OT, (b) PPD, (c) PMV, (d) rH, (e) DH, and (f) energy consumption due to AC only.

In the case of hours of discomfort hours (Figure 3(e)), the HVA presented the higher values, exceeding the $300 \mathrm{~h}$, in the three locations throughout the year, and even exceeded $350 \mathrm{~h}$ in March, from June to September, and from November to December. This before is in accordance with the results OT values for HVA presented before. The HCA and HRES showed fewer hours compared to HVA, between 250 and $300 \mathrm{~h}$ for the different locations. Regarding the cooling load for all houses (Figure 3(f)), when comparing the different cases, it is observed that those with the highest consumption are HVA 3, HCA 3, HRES 3 (in location 3), followed by HVA 2, HCA 2, HRES 2 (in location 2). Moreover, the lowest consumption encountered was for HVA 1, HCA 1, HRES 1 (in location 1). The latter may be explained because in location 1, as shown in Figure 1, it is surrounded mostly by vegetation. 


\subsection{Bioclimatic analysis for Panama City}

A preliminary bioclimatic analysis was performed to determine proposed passive strategies suggested by the Givoni's and Olgyay's charts, using the bioclimarq ${ }^{2016}$ [22] tool and the corresponding meteorological data. Results showed that for the months January to April, Givoni's chart (a psychrometric-based chart) suggests the implementation of diurnal natural ventilation strategies combined with high thermal mass and nocturnal natural ventilation strategies. From August to December, diurnal natural ventilation is suggested for most of the time. However, from May to July, diurnal natural ventilation is no longer recommended with high risks of need for artificial ventilation and air conditioning. Results from Olgyay's chart (temperature vs. relative humidity) suggests that natural ventilation should be a critical parameter for the building design, for all months.

Furthermore, results from Mahoney's tables showed that the meteorological data could be classified as a warm, humid climate. Natural ventilation also appears to be essential for the whole year, as suggested from Olgyay's chart, where the following strategies are recommended: $(i)$ a North-South orientation with an extended building configuration along the East-West to facilitate cross-ventilation; (ii) external walls and floors with lightweight materials; (iii) usage of outdoor spaces are not recommended; (iv) the use of spans are highly recommended with coverage between $50 \%$ and $80 \%$ facade surface area at occupants' height, and facing dominants winds with total and permanent shading.

Moreover, results from Serra \& Coch's tables and coefficients recommend buildings with low slenderness (no high buildings), and minimum possible building surface area in contact with the ground. Also, lightweight materials for the envelope, along with low insulation, are recommended, and smooth facades with bright colours.

In summary, the bioclimatic analysis has shown that the bioclimatic strategies for a warm, humid climate do share compatibility with the strategies recommended by other researches presented earlier in Table 1. The strategies implemented in the HVA (which strategies have been employed since the primitive architecture in Panama [18]) serve to reduce the $\mathrm{rH}$ levels as confirmed via simulations and also recommended by recent studies $[6,10]$.

\section{Conclusions}

Different bioclimatic architecture strategies have been assessed, in the present work, firstly through a literature review specifically regarding previous studies implementing bioclimatic strategies for tropical climates and the evolution of the vernacular architecture in Panama. Secondly, a numerical assessment was performed to compared thermal comfort performance between a remaining vernacular architecture house (HVA) and a current standard house architecture (HCA). Additionally, this comparison includes a current standard house architecture but accounting for the recent building regulations in Panama (named HRES). Thirdly, the assessment finishes with the implementation of Givoni's and Olgyay's bioclimatic charts along with Mahoney's and Serra \& Coch's tables. All three houses, the HVA, HCA, and HRES, were tested in three different locations within Panama City. Results showed that the strategies in HVA perform best for reducing $\mathrm{rH}$ levels, but the HRES performs best in overall thermal comfort performance, apart yet from the high $\mathrm{rH}$ levels encountered. In future studies, optimization techniques are to be implemented with the intention to further achieve better thermal comfort performances. 


\section{Acknowledgements}

This publication is part of the project FID18-056, which has received funding from Secretaria Nacional de Ciencia, Tecnología e Innovación (SENACYT). The authors would like to thank the Faculty of Mechanical Engineering, as part of the research group in Energy and Comfort in Bioclimatic Buildings (ECEB in Spanish), within the Universidad Tecnológica de Panama for their collaboration on this work.

\section{References}

1. JTIA, Reglamento de edificación sostenible de Panamá (2019), Building regulation

2. Secretaría Nacional de Energía, Guía de construcción sostenible para el ahorro de energía en edificaciones. pp. 1-53, (2016)

3. X. Shi, Z. Tian, W. Chen, B. Si, and X. Jin, Renew. Sustain. Energy Rev., 65, no. November, pp. 872-884, (2016)

4. S. Luciani, Rev. Arquit., 16, pp. 2013-2014, (2014)

5. X. Zhou, F. Zheng, H. Li, and C. Lu, Energy Build., 42 (7), pp. 1070-1074, (2010)

6. D. Rayter. Guía de aplicación de arquitectura bioclimática en locales educativos. Lima, Perú, (2008)

7. F. Fantozzi, H. Hamdi, M. Rocca, and S. Vegnuti, Sustainability, 11, no. 6, Art. no. 6, Jan. (2019)

8. E. Vargas Soto, Revistarquis, 9, no. 1, pp. 27-46, (2019)

9. F. Leccese, Bozen (Italy), p. 8, [Online]. Available: http://www.ibpsa.org/proceedings/BSA2015/9788860460745_29.pdf.

10. E. G. Castillo, E. Coronado, and O. Osejo, Municipio de Managua, Nicaragua, PhD Thesis, Universidad Nacional de Ingenieria, (2014)

11. L. Peña, 2015th ed. Ciudad de Juárez, Chihuaha, México: General de Difusión Cultural y Divulgación Científica Coordinación, (2015)

12. A. Velasco and J. Alvarado. Transformación de la vivienda social con cualidades bioclimáticas. Ciudad Juárez, (2015)

13. J. López, A. Govea, and G. Bojórquez, Acad. J., 11, no. 7, pp. 507-513, (2019)

14. D. los Á. María, PhD Thesis, Universidad Politécnica de Valencia, (2013)

15. J. Araúz, D. Mora, and M. Chen Austin, in 2019 7th International Engineering, Sciences and Technology Conference (IESTEC), pp. 209-214, (2019)

16. D. Mora, J. Araúz, and M. Chen Austin, in ATI 2019, Modena, Italy, (2019)

17. M. Zune, L. Rodrigues, and M. Gillott, Sustain. Cities Soc., 54, p. 101992, Mar. (2020)

18. S. Guitiérrez, Arquitectura panameña: Descripción e historia. Panamá, (1999)

19. E. Tejeira, La arquitectura del canal de Panamá: Colonialismo, sincretismo y adaptación al trópico. Inst. Arquit. Trop.

20. E. Tejeira Davis, El Casco Antiguo de Panamá. p. 38, (2007)

21. V. Spadafora and E. Tejeira, Angel Morú. Panamá: United Nations Development programme PNUD, Office of the Old Quarter.

22. J. Rincón Martínez and V. Fuentes Freixanet, "Rayter," Univ. Autónoma Metrop. Unidad Azcapotzalco, (2016) 